\title{
517 ニューラルネットワークによる散水消雪施設運転支援システムの開発 \\ Development of Operation Support System of Sprinkler Snow-Melting Equipment using Neural Network
}

\author{
正 樋口 良之（福島大） ○ 三野宮 裕規（福島大）
}

Yoshiyuki HIGUCHI, Fukushima University, 1 Kanayagawa Fukushima City, Fukushima, 960-1296 Japan.

Yuki SANNOMIYA, Fukushima University.

The sprinkler snow-melting equipment is operated by local inhabitants whom local public entity entrusted. There is a difference in an operating experience and the knowledge of the equipment for entrusted operators. In addition, the operator can do only the change of the ON and OFF of the water pump, cannot operate water temperature and quantity of sprinkling. In this study, an operating support system by the neural network which learned the judgment of the expert operator and the knowledge of the road with sprinkler snow-melting equipment, was developed.

Key Words : Sprinkler Snow-Melting Equipment, Operation Support, Neural Network, Winter Road

\section{1. 緒 言}

道路水消雪（散水消雪）の施設が設置されて，約 40 年が 経過しようとしている.この施設は地域において降䨒時の経 済活動の停滞を無くすために, 排雪場所の確保が困難で機械 除雪が適さず，かつ，経済活動上の重要な路線を選定して設 置されてきた. 現在まで様々な道路構造, 形態での活用がな されているが, これらの散水消雪施設を対象にした研究は少 ない，それらの研究の成果は，路面消・融雪施設等設計要領 (1)などに集約され，散水消雪施設の設計実務者に有効な資 料として提供されている，これらの研究の対象は，散水消雪 施設の計画，設計，設置（施工），保守保全を主体にしたも のが多く，設置後のオペレータの運用に関する検討は少なく， 施設設置後の有効運用について検討の余地が残るところであ る，特に，地域住民の要望を考慮した散水消雪施設の有効利 用, 消雪水のはね, 状況にあわせた適切な施設稼働などの課 題を考慮した施設運用の検討は，重要な課題である.

本調查研究では, 散水消雪施設の適切な運用を実現するし くみの提案を目指し，散水消雪のメカニズムを検討した.こ のために, 散水消雪施設の稼働時刻, 散水道路状況などを調 查した ${ }^{(2)}$. 本報は散水消雪施設の操作者を支援する運転支 援システムを検討する.

\section{2. 散水消雪の動向}

本研究の対象である道路水消雪設備とは, 図 1 に示す消・ 融雪施設の中でも散水消雪施設, いわゆる, 消雪パイプのこ とである. この散水消雪施設の中でも, 特に, その多くを占 める地下水と河川水を利用したものを対象としている. 道路 における水を活用した消雪では，路面流水工などの流水施設 もあるが，本研究では対象としない。

散水消雪の利点は，散水地点から排水口まで無雪路面を確 保できることである. 特に, 主流のロータリ式除雪機械など を使用した機械除雪と異なり, 雪捨て場を必要としない. 車 両通行によるタイヤの擋找によって消雪ムラが解消され，消

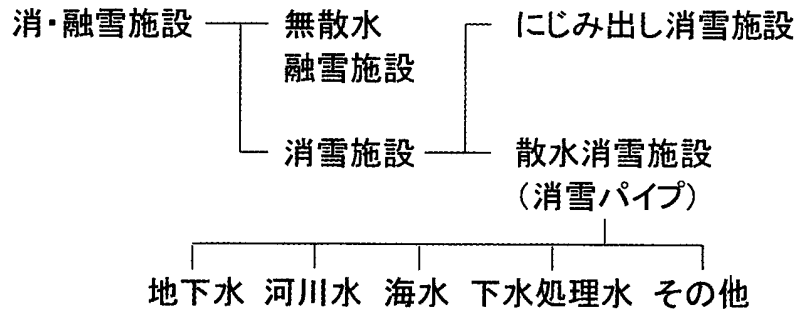

Fig.1 Classification of sprinkler snow-melting equipment

雪効果が高まる.これらのことから，密集した商業，住宅地 域などに適切である，また，機械除雪に次いで，経済的之言 われている，さらに，施工にあたっては，道路全体（面）で の工事ではなく，消雪パイプ (線) に沿った工事であり，融 雪施設などと比べて比較的小さな工事である.

一方，散水消雪は気温と水源以外にも様々な制約を受け， 車両通行に伴う歩行者と設置物一の消雪水のはね, その凍結 による設置物の故障が発生するなどの課題も多い，また，少 子高齢社会の深化，生活環境亡意識の向上，地方自治体の予 算削減により, 散水消雪への要望，クレームも増え，散水消 雪に対する地域住民の期待と不満は，毎年，高まっている.

\section{3. 散水消霓の運転モデルの必要性}

本研究で行った実地調查で理解が哚まったことの一つに, 散水消雪施設の運転を委託された者が，その運転について悩 みを抱えていることである. 散水消雪施設は, 設置道路の管 理者である国や県，自治体により計画，設置され，保守保全 され，その運転については，刻々と変わる天候，路面状況な どに対応できるように，自治体から設置地区の方に委託する ことも多い. 散水消雪施設の運転操作をする方の経験は多様 で，施設設置以来の継続している方，親子 2 世代にわたり， ウハウを引き継ぎながら今日に至っている方， $2 ， 3$ 年の任 期の当番で担当している方など，経験年数，苦労など様々で ある．操作者は，様々な経験，天気予報などの予測，地域の 要望などを考慮し操作するが，できることは，揚水ポンプの

[No. 2009-2］ 日本機械学会＼cjkstart東北支部第45期秋季講演会 講演論文集（2009.9.26） 
電源スイッチのオンとオフの切り替えの一つだけである.

現在では，この揚水ポンプの電源スイッチのオンとオフの 切り替えを, 気温, 路面温度, 降雪量などをモニタリングし, 自動化する施設もある. 一方，施設の老朽化，取水量の低下， 降雪や気温低下の前から対応する必要性や天候回復後にも散 水の必要性があるなどの事情に応じた, より柔軟な判断操作 が求められる地域も存在する.

この柔軟な判断操作が操作者の精神的な負担となることが ある。柔軟な判断操作は, 地域住民の間での評価に差異を生 じさせる，とりわけ，道路の消雪に少しでも寄与すればいい といった散水消雪施設が導入されたばかりの時代と異なり， 水は水など散水消雪への評価も多様になり, 地域住民の評価 が柔軟な判断操作を行う操作者に向けられる事例がある. 柔 軟な判断は同じ時刻と場所であっても差異があり，地域住民 の評価では，良い評価について操作者に伝わりにくく，多く の場合, 悪い評価について操作者に伝わる.また, この悪い 評価は，地域全体でとらえると少数意見である場合，また， 経験のある操作者が数時間後の状況を考えた適切な判断に対 して向けられる場合もある。

本研究では，この柔軟な判断操作について，推論を使った 判断操作モデルを構築する.この判断操作モデルを活用する ことで, 経験の少ない操作者や地域住民の理解をも樑めるこ とを支援する.

\section{4. ニューラルネットワークによるモデリング}

本研究では, 経験のある操作者のより柔軟な判断操作, 地 域の特質を考慮した判断操作についてモデルを構築する。モ デルに状況, 条件などを入力し, 判断操作を出力するシステ ムを設計する.

このように入力值から出力值を出すシステムは多々存在す る。条件を比較的に簡単に仮定すれば，入力值から出力值を 数式などで唯一確定的に算定する方法がある。一方, 入力と 出力を明確に関連付けることが困難であったり，異なる環境 でも運用させる必要があったりする場合，推論を用いる場合 がある. 本研究の対象のように，もともと同じ状海，条件下 でも，人によって判断結果が異なるような場合，推論を用い ることが多い. 推論には, ファジィ理論, ニューラルネット ワークなどの適用がある、本研究では, 経験のある操作者の 判断操作を採り入れやすいニューラルネットワークに基づき, 推論モデルによる操作判断出力システムを設計する.

本研究で行った操作者へのヒアリングの結果, 操作者が判 断に用いるデータには，次のものがあることがわかった．

- 現在の状況（散水状況（揚水ポンプのオンとオフ）, 気温, 降雪量, 路面状況)

\section{· 天気予報 (気温の变化, 降雪量変化)}

また, 判断結果として, まず, 第一に, 揚水ポンプのオンと オフの操作があげられる. 本研究の調查では, 心労を重ねて いる操作者が，昼夜を問わず天気予報と実地の状況を見なが ら, 頻繁に判断を繰り返し, 操作盤へ足を運んでいることか ら, 次の判断を行うまでの時間も判断結果として提供するこ とを考えた。これらの入出力項目を簡易なニューラルネット ワークで簡便に表現すると図 2 となる，7つの入力項目と 2 つの出力項目の值についは，定量的なものと定性的なものが

\section{Input layer Interlayer Outputlayer}

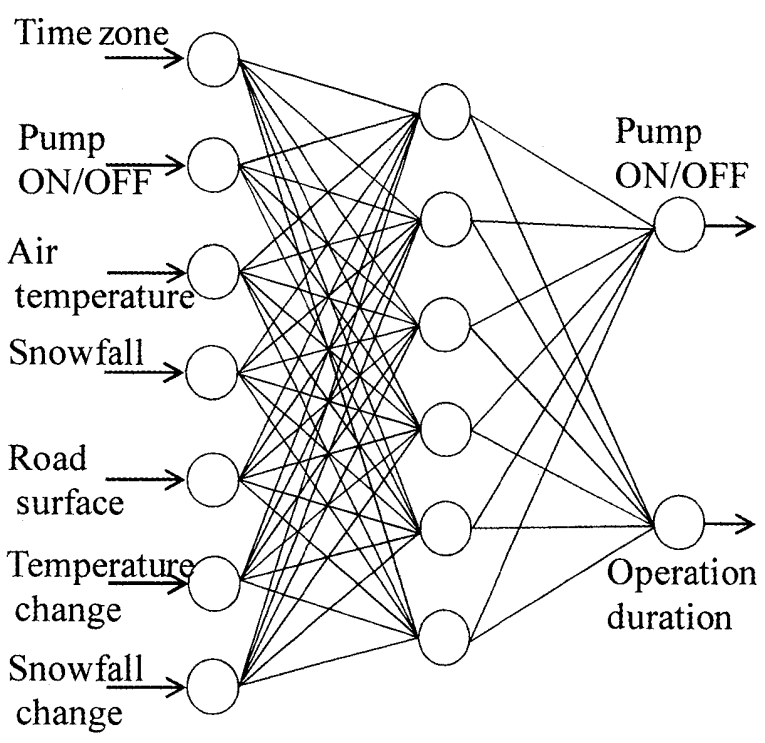

Fig.2 Neural network model of operation support system

ある，とりわけ，定性的なものについては，例えば，凍結路 面は 0.8, ドライ路面は 0 というように，変換テーブルを用意 して定量化している.

適切な教師信号を設定し，その教師信号を学習したニュー ラルネットワークを利用する。これにより，あらゆる散水消 雪施設に応用できる可能性を持っているが，現実的には，機 器の老朽化や取水量の変化, 住民の思考の差異などによって, 地域ごとに同じ教師信号で学習したニューラルネットワーク の運転モデルを運用することは合理的ではない，

\section{5. 結 产}

散水消雪施設の運転は，地方公共団体が委託した地域住民 が担当する. 委託された者の散水消雪施設の運転経験と知識 には差異がある、また，委託された者は，揚水ポンプのオ ン・オフの切換えのみ操作でき，水温や散水量を調整するこ とはできない，そこで，地域住民などの理解を深めたり，経 験の浅い操作者を支援するために，熟練操作者の判断や消霓 道路の知識を学習させたニューラルネットワークによる運転 支援システムを開発した。

今後の展䦕として，これまで収集してきた熟練オペレータ のデータを学習させたニューラルネットワークを用いて, 様々な状況での操作指示マニュアルを作成し，それに基づき 運転した場合の道路状況を観察し，モデルとマニュアルの評 価を行う予定である.

本調査研究は, 財団法人日本積雪連合の平成 19 年度と平 成 20 年度の調查・研究委託事業の一つとして実施されたも のである，最後に，実地調查にご協力をいただいた福島県只 見町の関係各位に檿くお礼申し上げる.

\section{文 献}

（1）建設省北陸地方建設局道路部，路面消・融雪施設等設計要 領, (2008).

（2）樋口良之, 道路水消雪設備モデルの確立と適切な設計と運 用の検討，日本積雪連合，(2009）。 